\title{
Developing Blended Entrepreneurship Model As an Effort to Increase The Economics of Persit Kartika Candra Kirana And Society in General
}

\author{
Heny Kusdiyanti \\ Lulu NurulIstanti, Grisvia Agustin
}

\begin{abstract}
PERSIT is the biggest support for accompanying husbands' duty for their responsibility as coutry's guard that most of them are unemployed housewives who do not make money by themselves. Whereas, they are potentially capable of doing that since they have much sparetime to do positive activities in order to avoide PERSIT boredom in accompanying their husbands. An appropriate activity is entrepreneurship activity that can increase the economics of family. In PERSIT organization, there is economic division that in fact it has not been realized well because of the entrepreneurship competence and business skill of PERSIT women that have not been developed. This condition cannot be avoided, so there should be a serious effort to employ PERSIT Kartika Candra Kirana especially those who live in Malang to increase their entrepreneurship competence and business skill. This study is expected to give contribution to increase human resource quality and productivity of PERSIT Kartika Candra Kirana in Malang. This study aims to develop business assistance and consultation model and Blended Entrepreneurship assistance for PERSIT Kartika Candra Kirana in Malang. The first stages are as follows: (1) Analysis of situation (environment), (2) Identification of respondents characteristics, (3) Identification of real needs of respondents, (4) Arranging Blended Entrepreneurship assistance model and business consultation for PERSIT Kartika Candra Kirana in Malang based on analysis of situation, identification of characteristics and respondents' real needs.
\end{abstract}

Keywords: Model, Entrepreneurship, Blended Entrepreneurship, Kartika Candra Kirana

\section{Introduction}

PERSIT Kartika Candra Kirana in Malang, a traditional role of entrepreneur can be seen basen on the contribution of traditional small and mediun entreprises (PERSIT Kartika Candra Kirana in Malang) to regional economics. Based on macroeconomics principal, the traditional small and medium entreprises can save regional economics in the process of betterment. Its role in supporting economic growth and employing manpower is expected to be the first step to activate production sector in various work field. In many regions, developing entrepreneurship has been national program in building competitive superiority and as an entrepreneurship lesson as a part of developing life skills of society.

Based on business condition of 200 PERSIT Kartika Candra Kirana in Malang, the data are as follows: (1) $57 \%$ respondents did not face difficulties in getting the goods, (2) $43 \%$ respondents faced difficulties in selling their products, (3) $87 \%$ respondents did not have knowledge about how to run and develop their business with limited finance, (4) $18 \%$ respondents were interested in looking for information about manufacturing, (5) $57 \%$ respondents stated thatit is not the matter of financial needs, (6) $41 \%$ respondents stated the problems about adding budget as the capital and income resource that has fast process, (7) 53\% respondents stated their willingness to develop business in order to increase the income, (8) $47 \%$ respondents faced difficulties in manufacturing of previous business, so there was no plan to create new business activity in different form.

There are three issues that show that the empowerment of traditional small entreprises should be directed to the effort of increasing entrepreneurship competency that heads to the realization of high entrepreneurship so it can give contribution for overall economics (macroeconomics). The empowerment of traditional small entreprises is no longer to achieve shor-term target or only cover capital deficiency that is in fact not effective. As the effort to increase traditional small and medium entreprises in Malang, the empowerment of traditional small and medium entreprises through learning process should be under consideration where small entrepreneurs are asked to participate in increasing the capability of independent business through various educational activities and training. According to the previous description, it can be concluded that learning process is obviously needed by entrepreneurs in order to develop their skill and business. The researcher wants to know further factors of entrepreneurship learning as the effort of business continuity of PERSIT Kartika Candra Kirana in Malang. 


\section{Research Objectives}

The general objective of this reseach is developing Blended Entrepreneurship model to createbusiness assistanceand consultation in entrepreneurship field for PERSIT Kartika Candra Kirana in Malang. While the specific objectives are as following:

1. Implementing business assistance consultation model for PERSIT Kartika Candra Kirana in Malang.

2. Organizing evaluation of business assistance and consultation model for PERSIT Kartika Candra Kirana in Malang.

3. Creating revision of business assistance and consultation model for PERSIT Kartika Candra Kirana in Malang so it will produce well-tested model.

4. Creating revision of implementation of Manual of business assistance and consultation in the form of: (a) Scenario of assistance and business consultation, (b) Materials/ curriculum of assistance and business consultation, (c) assistance manual book, (d) assistance and business consultation syllabus.

5. Producing journal article of research result to be published in national accredited journal.

\section{A. Basic Concept}

\section{Literature Review}

Researches in society field, especially coastal society, in many regions in Indonesia have shown clear image that soco-economic problems, like poverty, social gap, limited access of education and health, weak social institution, dificulties of business capital access, technology, and market are serious problems which should be overcomed (Mubyarto dkk. 1984, Masyuri, 1999; Kusnadi, 2002, Imron, 2003). The impacts of those problems are the disruption of socio-economic access, and technology of rural society that can decrease human resource quality, cause limited environmental resource empowerment, and also rural area that is not capable of supporting economics growth. The government has made policy to overcome social problems to be intensively implemented.

The paradigm of empowerment of poverty society program is based on relevant elements with cultural characteristics and socio-economic needs. The elements which should be considered are described in the following sentences. The first aspect is that the existance of empathy-simpathy characteristic by means there should be awareness of society of the future life whether in the form of program realization or society itself. This characteristic is crucial since the cultural capital to build up the awarness of various parties that any empowerment program is really directed to increase prosperity. All parties should participate in keeping the program running. The second one is focusing on social groups which are economically susceptible. It should be done to make sure that the empowerment is not taken over by inappropriate parties. The third one is that the program should be participation-oriented that the society should participate in planning, doing, monitoring, and evaluating the program. Those are important in order to make the society really act as the empowerment subject. They are the ones who know the needs of their life. They also understand whether particular program is successful or failed based on contextual-local parameter. The bureasucrat, non government industry, and other parties which participate in the empowernment process should take role as mediator, facilitator, and catalisator.

As one of approaches in building society and community, social and economical institutions have strategic value because of some matters, which are (1) as a place for aspiration and aspiration organizer of society building, (2) collecting all social, economic, politics, and cultural potential of society that can me the increase of colective capability, resources, and society access, (3) strengthening solidarity and social cohesivity so the ability of working together is increased, (4) increase the ability of bargaining position of society to parties over the village, and (5) developing colective responsibility of building region (Syafullah dkk.2003).

The increase of economic programs in society and social prosperity have a big contribution in developing human resource quality of PERSIT Kartika Candra Kirana in Malang. With their ability of managing provided natural resource, this will guarantee the building activities which are continually organized by PERSIT Kartika Candra Kirana in Malang. In this context, the empowerment of PERSIT Kartika Candra Kirana in Malang is an important thing that should be given more attention from many parties. Every entrepreneur wants the appropriate development and increase of business. Various efforts and ways are done in order to succeed their business, for example by making more outlets, increasing production and marketing capasity, and expanding business scale. Moreover, some of them try to do business diversification or expanding business in a new field. Althoughthe term of business diversification has not been familiar for some of small business owner, many people have done it without knowing the term. The principal is that how to find new opportunity of business and increase the income (Kusdiyanti, 2013).

Training the entrepreneurship of society technically can be done through various ways, for example by giving training, consultation, assistance, guidance,etc. Each of that way should be in line with the characteristics and condition of the society. The training for small entreprisein the form of training is usually done to develop the quality of human resource for the business that has been already exist, in order to increase business owner work(Kusdiyanti, 2011). This research is to make entrepreneurship training model that based on and has 
assumption: (1) Developing innovative characteristic in looking at the business as potential power to economic activity, with the assumption of learning result attitude so it can be trained and developed; (2) Increasing insights and skills related to utilization business for economic/productive activity, the same as previous aspect that insights are the results of learning that can be increased; (3) The low attitute and knowledge can be trained (Kusdiyanti, 2011).

\section{B. Blended Entrepreneurship Assistance Model and Business Consultation}

Blended Entrepreneurship is adapted from Blended theory that is integrated with the concept stated by J. Fauconnier and M. Tunner as developmental theory of mental capasity in the form of double-scope blending because Blended concept is dynamic concept that has thoughts and applications. The points of this theory are formulated as follows:

a. Unique fiture of human in his capasity to give life meaning

b. Main method of implementation of double-scope blending work capasity to develop integrated mental.

The example of Blended concept ilustration is two Buddhists who climb mountain everyday and reach the top in the afternoon and go down in the evening, with the assumption that they do not stop during the journey (Fauconnier and Turner, 2002: 39). Both Buddhists have different concepts in their journey. Those concepts are illustrated in the following scheme:

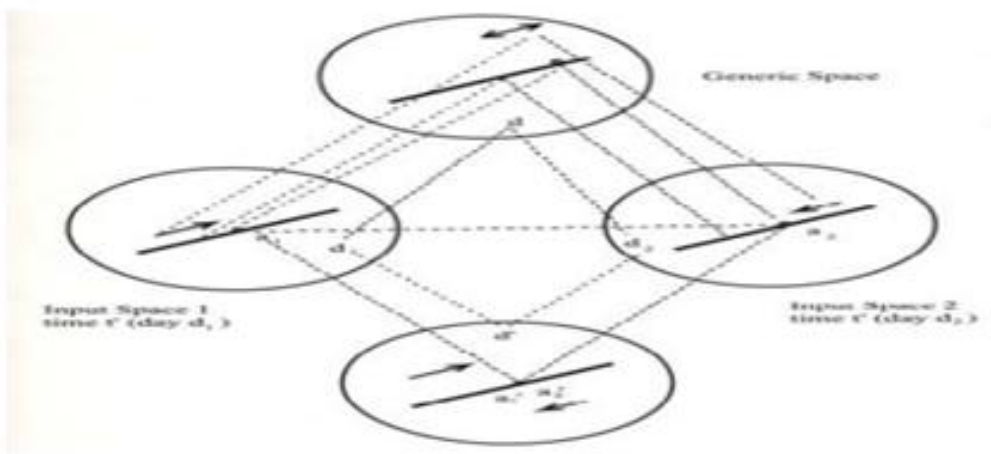

Figure 2.1 Blended Concept in Buddha(Source: Fauconnier and Turner, 2002: 39)

We can see from the scheme that there are different inputs which are blended space and generic space. Blended space is irregular form. The scheme shows that one o Buddhists has different rute to climb the mountain. Besides, the generic space is regular form that is the same every day. The example given in the scheme shows that other Buddhist walks by similar path other mountain climbers (ibid, 41). Double-scope blend is the combination of unstructured blended scope and structured scope. Unique human capasity differenciate him with other creatures. That is why in human's life, being in only one scope is impossible. Human consists of structured blood vessel.However, human always has different personality one another that makes it impossible for human to be always structured or unstructured.

Therefore, developing Blended Entrepreneurship model is really appropriate with PERSIT Kartika Candra Kirana and society in general because they have educational background and are interested in different business. However, they have the same objective that is developing continous business.Before giving more explanation about how to develop entrepreneurship assistance model and business consultation, the definition of assistance and business consultation should be explained first. According to Satmoko and Irmin (2004), business assistance and consultation is an effort to develop knowledge, work competence, skills, productivity and prosperity of participants of business assistance and consultation. Besides, Leonarde (2002) defines business assistance and consultation as (1) activity to engange individual with the work and organization (2) one of processes that needs to change new organization member to be productive "intern person" (3) a process to make a better individual (4) business assistance and consultation: a structured learning experience process to develop knowledge, attitude, and skill (structured: schedule, material, method, evaluation, etc). Based on the two previous definitions, it can be concluded that training activity actually aims to increase the quality of someone's utility for his/her work so he/she can be more productive. Moreover, Subejo (2009) states that a business assistance and consultation can be successful if it has implemented process related to the following things:

(1) Devending competence

There is always tendency of every person to work individually as entrepreneur or as employee and experience the lowest competence (incompetence). The indication happens if someone becomes less productive. It can be solved by giving business assistance and consultation. 
(2) Speeding up acceleration process

The acceleration process should be done as an effort to catch up. The existance of competition that is more complex so we need an effort to speed up to catch up. Acceleration can increase knowledge, attitute, and skill in shoter time.

(3) Being able to build self-confidence of business assistance and consultation participants

Business assistance and consultation that is given intensively to unskill labour can increase "work spirit" because they more understand how to increase their self capability, so there will be no doubt and in the end they can buld up "self-confidence".

\section{Implementation Planning of Blended Entrepreneurship Business Assistance and Consultation for Society}

Design of business assistance and consultation needs to focus on answering question when business assistance and consultation is needed. The answer is that business assisstance and consultation are needed in appropriate time (related to participants' individual motivation). According to Yuyun (2005), there are some important conditions which needs to be considered in designing business assistance and consultation; (1) There is real competence that should be achieved in terms of helping participants to have better life (2) There is change (micro and macro) in society life or an organization that makes society should be also changed according the change happens (3) business assistance and consultation is the effort to develop someone's capability (development) so the socialiteand the leader should participate in the training done in particular organization (4) Business assistance and consultation is expected to increase knowledge, skill, and attitude. These can be fulfilled if related partyis ready mentally and phisically to do the training (5) Reinforcement. The participants of business assistance and consultation mostly have achieved knowledge in formal education, but sometimes theories cannot be applied directly so reinforcement is needed (6) Work Adaptation. After finishing business assistance and consultation, the participants should be able to apply it in daily life. Therefore, the design of training should anticipate how far the development of work that will happen in the future (for example the development of technology, information, and communication.

\section{Research Method}

This reseach is descriptive quantilative research that is combination of descriptive quantitative and descriptive qualitative approaches. The approach used in this research is emik (emik view) (Pelto and Pelto, 1978:54-66). This approach places PERSITKartika Candra Kirana in Malang as the autonomous subject in giving opinion and perception about empowerment entrepreneurship competency for the running of the businessto their economic dynamic and living.The research informants as the sources of the research data are PERSITKartika Candra Kirana in Malang including the business owner, socialite, both formal and informal. The number of informats is relative and decided based on the needs of data analysis. The method of model implementation will be done by implementing and observing which are the main methods of descriptive qualitative research (Spradley, 1979 and 1997). By using triangulation approach, the data which have been collectet are expected to be valid and reliable. The data which are going to be the description object of this research are primary and secondary data. The primary data are obtained through indepth interview with the informants and participant observation to economic condition, economic activity of Kartika Candra Kirana in Malang. the secondary data are in the form of statistical data, legal documents, relevant literatures, and so on which are from various sources. Those data are going to be gathered, categorized, and interpreted and analyzed the meaning integratively inter-component of the subject. The results of analysis are going to be presented comprehesively in the form of descriptive qualitative by considering theoritical framework and concepts as the references of this research. The data were analyzed using descriptive analysis that covers the activity of analyzing situation (environment), respondents' characteristics and repondents' needs of business assistance and consultation that will be implemented. The analysis of respondents' characteristics covers: respondents' education background, respondents' children, respondents' income, respondents' training participation to support their business, respondents' knowledge about entrepreneurship problems and business planning. Those characteristics are needed as the information used in planning, model of business assistance and consultation, the media, and instructors who are participated in business assistance and consultation if the model created is suitable.The analysis of respondents' real needs covers: the level of respondents' needs of business assistance and consultation, the materials needed; whether entrepreneurship materials, business planning, or accounting which are also important for them, the respondents' belief towards benefits of business assistance and consultation, business planning and the respondents' needs of business assistance. In the end of the program, they can produce a representative model to increase new entrepreneurs. The next analysis is the results of implementation of model that has been tried out in a small scale, evaluated by expert and researcher, revised, and validated to be tried out in a big scale. The betterment of entrepreneurship condition which are expected after finishing this research is a competitive economic condition globally. 


\section{Results}

Table 1. Practical Acivity of Entrepreneurship

\begin{tabular}{|cl|l|l|l|l|}
\hline & & Frequency & Percentage & Valid percentage & $\begin{array}{l}\text { Cumulative } \\
\text { percentage }\end{array}$ \\
\hline 1. & Very Low $(11-19.25)$ & 50 & 24.4 & 24.4 & 24.4 \\
2. & Low $(>19.25-27.50)$ & 82 & 40.0 & 40.0 & 64.4 \\
3. & High $(>27.50-35.75)$ & 44 & 21.5 & 21.5 & 85.9 \\
4. & Very High $(>35.75-44)$ & 24 & 14.1 & 14.1 & \\
TOTAL & & & & 100.0 \\
\hline
\end{tabular}

According to the previous description, it can be concluded that entrepreneurship training is one of important ways to build and develop entrepreneurship spirit. One of basic problems that becomes biggest challenge is the problem of building economic. In this case, the problem faced is the more human resources in this world, the more jobless people will be.

Entrepreneurship is developmental potential in the form of number and quality of the business itself. In this free trade era, we should not only prepare the human resource that is ready to work but also prepare and open new job facancy. Opening and broadening job facancy are crucial needs. In order to open new job facancy, the entrepreneurship training is needed as a society component. However, the entrepreneurship training is not going to be successful without management, because of limited humans' capability (phisical, knowledge, time, and training) and the need is uncountable. Therefore, by creating management will build business that fulfilled the needs and limited capability in working and enhance people to define work, task, and responsibility, and in the end there will be organisation that can finish and help the work (Malayu S.P. Hasibuan, 2009:3). Looking at today's reality, we cannot avoid that global economic growth has been felt so we need to build competent human resources and ready to compete. That is why the need of entrepreneurship training cannot be delayed or avoided. It is suggested to apply entrepreneurship training that can build and develop entrepreneurship program like what one of institutions has done. Although only promoting education at the beginning, they have tried to solve socioeconomic problems since 1970 ( A Halim dkk, 2005: 207).

Table 2. Implementation of Entrepreneurship Training

\begin{tabular}{|c|l|l|l|l|}
\hline & Frequency & Persentage & $\begin{array}{l}\text { Valid } \\
\text { Persenage }\end{array}$ & $\begin{array}{l}\text { Cumulative } \\
\text { Persentage }\end{array}$ \\
\hline Very Low $(15-26.25)$ & 64 & 31.2 & 31.2 & 31.2 \\
2. Low $(>26.25-37.50)$ & 96 & 46.8 & 46.8 & 78.0 \\
3. High $(>37.50-48.75)$ & 30 & 14.6 & 14.6 & 92.7 \\
$4 . \quad$ Very High $(>48.75-60)$ & 10 & 7.3 & 7.3 & \\
TOTAL & 200 & 100.0 & 100.0 & 100.0 \\
\hline
\end{tabular}

It can be concluded that the objective of entrepreneurship training is giving participants knowledge about how to be a great entrepreneur and to be a holistic human, as a creature that has characteristic, understanidng, and skill as an entrepreneur.Characteristic, according to Leland and Jacob, is the pattern of behaviour characteristics for given individual. Behaviouristic psichologists believe that characteristics are similar with attitude, while in social psychology, humans are always related to other humans, nature, and themselves.

Entrepreneurship that is given aims to shape holistic human, as a creature that has characteristic, understanidng, and skill as an entrepreneur. It also aims to increase the numer of high quality intrepreneur, creating entrepreneur' capability and stability to make the advancement and prosperyty of society, civilizing spirit, attitude, character, and entrepreneurship capability for the students and society which are capable, reliable, and superior.

Table 3. Readiness to Run Business

\begin{tabular}{|c|l|l|l|l|}
\hline & Frequency & Persentage & $\begin{array}{l}\text { Valid } \\
\text { Persentage }\end{array}$ & $\begin{array}{l}\text { Cumulative } \\
\text { Persentage }\end{array}$ \\
\hline Very Low (22-38.50) & & & 26.8 & 26.8 \\
2. Low $(>38.50-55)$ & 80 & 26.8 & 42.9 & 69.8 \\
3. High $(>55-71.50)$ & 44 & 21.5 & 21.5 & 91.2 \\
4. Very High $(>71.50-88)$ & 18 & 8.8 & 8.8 & \\
TOTAL & 200 & 100.0 & 100.0 & 100.0 \\
\hline
\end{tabular}

According to the readiness to run a business, they are not ready to run business because they are lack of practical experince. The causes are: (1) the instructor is not ready to train entrepreneurship; (2) most entrepreneurs are lack of knowledge so there are only some instructors who have higher education background that causes less effective training; (3) low discipline. It may be caused by lack of business preparation; (4) work 
training is not really effective; (5) big and mediun industry felt burdened by the presence of begginer intrepreneur because of the lack of training; (6) big and medium business make insurance as a requirement of the businessman, the industry does not take risk fatal accident during entrepreneurship practice.

Table 4. Family Background

\begin{tabular}{|c|l|l|l|l|}
\hline & Frequency & Persentage & $\begin{array}{l}\text { Valid } \\
\text { Persentage }\end{array}$ & $\begin{array}{l}\text { Cumulative } \\
\text { Persentage }\end{array}$ \\
\hline Very Low (14-24.50) & 52 & 25.4 & 25.4 & 25.4 \\
2. Low (> 24.50-35) & 90 & 46.3 & 46.3 & 71.7 \\
3. High $(>35-45.50)$ & 39 & 19.0 & 19.0 & 90.7 \\
$4 . \quad$ Very High $(>45.50-56)$ & 19 & 9.3 & 9.3 & \\
TOTAL & 200 & 100.0 & 100.0 & 100.0 \\
\hline
\end{tabular}

According to the data, family is basically the smallest unit of social system in the society. As the smallest unit, family is a miniatur and embryo of various social system elements of human. A condusive family circumtance will produce a good society because all family members learn kinds of the basic of society life from the family. The development of civilitation and culture, especially science and technology, that is rapidly developed positively and negatively causes family life also experiences many changes which are not suitable with family value. In this modern and globalization era, many people believe that living condition in society is from family.

Family is part of society whose role is very important to create a healthy culture. From family, education backgound of every individual is started. A good society order also comes from family. Therefore, it starts from family to build particular culture.The statistic of this reseach can be seen at the following table:

Table 5. Statistic

\begin{tabular}{|l|l|l|l|l|l|}
\hline & & $\begin{array}{l}\text { Family } \\
\text { Background }\end{array}$ & $\begin{array}{l}\text { Practical Activity of } \\
\text { Entrepreneurship }\end{array}$ & $\begin{array}{l}\text { Implementation of } \\
\text { Entrepreneurship } \\
\text { Learning }\end{array}$ & $\begin{array}{l}\text { The Readiness of } \\
\text { Running } \\
\text { Business }\end{array}$ \\
\hline N & Valid & 200 & 200 & 200 & 200 \\
Mean & Missing & 0 & 0 & 0 & 0 \\
Median & 32.20 & 25.96 & 32.09 & 50.01 \\
Mode & 31.00 & 25.00 & 31.00 & 48.00 \\
Std. & 23 & 26 & 36 & 36 \\
Deviation & 8.739 & 7.554 & 9.697 & 13.937 \\
Variance & 76.364 & 57.057 & 94.026 & 194.250 \\
Minimum & 20 & 14 & 57 & 31 \\
Maximum & 51 & 39 & 6579 & 83 \\
Sum & 6600 & 5322 & & 10253 \\
& & & & \\
\hline
\end{tabular}

\section{Conclusion}

We probably often hear the term that rich family will make rich children because they are accustomed to be rich. In line with the term that someone becomes an entrepreneur because his parents and most of his family are also entrepreneur. Those are incorrect thoughts. There are many entrepreneurs whose parents are entrepreneur. It does not mean that entrepreneurship is genetically inheritted. That is probably because of the strong atmosphere of entrepreneurship environement that influences particular people to be entrepreneur. It is our right to be an entrepreneur. All of us can be entrepreneur although we were not born as entrepreneur family member. There are many ways which we can do, such as (1) Joining formal education. Nowadays, many educational institutions, both middle and high, provide various entrepreneurship programs or subjects (2) Joining entrepreneurial learning. Many entrepreneurial learnings are held by inviting business experts and practitioners to build up entrepreneurial spirit, (3) Joining training. Various business simulations are given by training indoor or outdoor. By doing these trainings, our braveness and sensitivity to environmental changes will be tested and always corrected and developed.

Through various media, we can develop the spirit of entrepreneurship. By reading successfull entrepreneur biography, for example, watching TV, radio, magazine, newspaper, and other media which are accessable, we can develop the spirit of entrepreneurship in our soul. Through various media, every person can learn and develop it. We should be results-oriented and open-minded. An entrepreneur should have target that should be achieved. If they are failed, they always try to correct his failure. The success that has already been achieved by someone who has the spirit of entrepreneurship motivates him to reach another success for his life. The leadership is a key factor to be a successful entrepreneur. An entrepreneur should be brave to take risk and do everything based on racional thoughts. Those who are afraid of leading and taking responsibility will hardly 
achieve the success of running business. Bad characteristics such as lacking of self-confidence, too shy, afraid of making mistakes, and feeling inferior should be left behind if someone wants to be successful.

A successful entrepreneurs are usually those who have competences such as knowledge, skill, and individual quality including attitude, motivation, value, and behaviour to work/ do activities. The managerial skill is a main aspect that every entrepreneur should has. An entrepreneur should be capable of running the planning function, organizing, doing, and monitoring in order to reach the objectives of particular business. The capability of analizing and marjeting, managing human resources, material, money, facility, and enterprise resource is an absolute requirement to be a successful entrepreneur. There are two main ways to develop managerial capability which are formal and informal education. The formal education can be through institution like vocational high school, business and management school or through high education such as commerce administrative departments or management departments which spread in many colleges, public or private. Informal education is by joining seminar, training, and our own experiences.

\section{References}

[1]. Fauconnier, G. \& Turner, M. 1996. Blending as a CentralProcess of Grammar. In Goldberg A. (ed.). ConceptualStructure, Discourse, and Language. Stanford: CSLI Publications, 113-129.

[2]. 1998. Conceptual integrationnetworks. Cognitive science. 22, 2, 133-187.

[3]. 2000. Compression andglobal insight. Cognitive linguistics. 11, 3/4, 283-304

[4]. 2002. The Way We Think.Conceptual Blending and the Mind's Hidden Complexities.N. Y.: Basic Books. 2008. The Origin of Language as a Product of the Evolution of Modern Cognition.In Laks B. (ed.). [5]. 2008. The Origin of Language as a Product of the Evolution

[6]. Kusdiyanti, Heny. 2009. Peningkatan Kompetensi Usaha Sebagai Peluang Kewirausahaan UKM Tradisional. Malang

[7]. 2009. Peran kompetensi Kewirausahaan UKM Tradisional Pada Keberlangsungan Usaha. Malang

[8]. 2010. Pemberdayaan dan Konsultasi Bisnis Pengepul Sampah. Malang

[9]. 2011. Pemberdayaan mahasiswa dalam program PKM-K di Universistas Negeri Malang.

[10]. 2013. Eksplorasi Potensi dan Kompetensi Kewirausahaan ibu-ibu Persit Kartika Chandra Kirana . Malang

[11]. Kusnadi dkk. 2004. Evaluasi Program PEMP TA 2003 di Propinsi Jawa Timur untuk Kabupaten: Lumajang, Malang, Jember, Tulungagung, Situbondo, dan Sumenep. Surabaya: Konsorsium Kemitraan Bahari Regional Centre Jatim.

2006. 6 Tahun "Pemberdayaan Masyarakat Pesisir: Penguatan Kelembagaan Sosial Ekonomi dan Dinamika Pembangunan Kawasan Pesisir", Makalah diskusi yang disampaikan di hadapan staf Direktorat Pemberdayaan Masyarakat Pesisir, Ditjen Kelautan, Pesisir, dan Pulau-pulau Kecil, DKP, Jakarta, 17 Mei 2006.

[13]. Masyhuri. 1999. Pemberdayaan Nelayan Tertinggal dalam Mengatasi Krisis Ekonomi. Jakarta: LIPI.

[14]. Masyhuri Imron. 2003. "Kemiskinan dalam Masyarakat Nelayan”, dalam Jurnal Masyarakat dan Budaya 5 (1): $63-81$.

[15]. Mubyarto dkk. 1984. Nelayan dan Kemiskinan: Studi Ekonomi Anthropologi di Dua Desa Pantai. Jakarta: Rajawali Pers.

[16]. Pelto, Pertti J. Dan Gretel H. Pelto. 1978. Anthropological Research. Cambridge: Combridge University Press.

[17]. Rudito, Bambang dan Arif Budimanta. 2003. Metode dan Teknik Pengelolaan Community Development. Jakarta: ICSD.

[18]. Syaefullah, Budiyana dkk. 2003. Organisasi Berbasis Masyarakat. Jakarta: INCIS.

[19]. Prawiraranegara, A. Sidik. 1994. "Pokok-pokok Kebijaksanaan Pemerintah dalam Pembinaan dan Pengembangan Pengusaha Kecil”, dalam Djabaruddin Djohan dan Husni Rasyad (Peny.). Mencari Bentuk dan Metoda Pembinaan dan Pengembangan Usaha Kecil dan Sektor Informal. Jakarta: Friedrich Ebert Stiftung, hal. 1-13.

[20]. Spradley, James P. 1979. Participant Observation. New York: Holt, Rinehart and Winston

[21]. Yustika, Ahmad Erani. 2002. Pembangunan dan Krisis: Memetakan Perekonomian Indonesia. Jakarta: Grasindo.

[22]. 2003. Negara vs Kaum Miskin. Yogyakarta: Pustaka Pelajar. 